\title{
Intermittent parenteral administration of endotoxin triggers metabolic and immunological alterations typically associated with displaced abomasum and retained placenta in periparturient dairy cows
}

\author{
Q. Zebeli, ${ }^{\star} \dagger$ S. Sivaraman, ${ }^{\star}$ S. M. Dunn, ${ }^{*}$ and B. N. Ametaj ${ }^{\star 1}$ \\ *Department of Agricultural, Food and Nutritional Science, University of Alberta, Edmonton, AB, Canada T6G 2P5 \\ †Institute of Animal Nutrition, Department of Farm Animals and Veterinary Public Health, Vetmeduni Vienna, Veterinaerplatz 1 , \\ 1210 Vienna, Austria
}

\begin{abstract}
This study sought to investigate the effects of induced intermittent endotoxemia on plasma mediators of carbohydrate and lipid metabolism, humoral immunity, and clinical health status in periparturient dairy cows. Sixteen pregnant Holstein cows were blocked by parity and day of calving, and were randomly allocated to 1 of 2 different treatment groups. Eight cows were infused intravenously (i.v.) with $100 \mathrm{~mL}$ of sterile saline and served as the control group $(\mathrm{CON})$. The other 8 cows were infused i.v. with $100 \mathrm{~mL}$ of sterile saline containing 3 increasing doses of lipopolysaccharide (LPS), from Escherichia coli O111:B4, for 3 consecutive weeks during the 2 wk before and 1 wk after parturition as follows: (1) $0.01 \mu \mathrm{g}$ of LPS $/ \mathrm{kg}$ of body weight (BW) on $\mathrm{d}-14$ and -10 ; (2) $0.05 \mu \mathrm{g}$ of LPS $/ \mathrm{kg}$ of BW on $\mathrm{d}-7$ and -3 ; and (3) $0.1 \mu \mathrm{g}$ of LPS $/ \mathrm{kg}$ of BW on $\mathrm{d} 3$ and 7 postpartum. Nine blood samples were collected during the experimental period (i.e., from -14 to $28 \mathrm{~d}$ postpartum) and analyzed for calcium, zinc, iron, copper, glucose, lactate, $\beta$-hydroxybutyrate (BHBA), nonesterified fatty acids (NEFA), cholesterol, insulin, cortisol, serum amyloid A (SAA), lipopolysaccharide-binding protein (LBP), haptoglobin (Hp), and anti-LPS IgA, IgG, and IgM. Results showed that intermittently induced endotoxemia decreased feed intake and milk production and triggered alterations in plasma cholesterol, BHBA, Hp, $\mathrm{Ca}, \mathrm{Cu}$, and anti-LPS IgG and IgM. All of these changes were associated with a greater number of cows affected by metabolic disorders such as left displaced abomasum (LDA, 2 from 8 LPS cows vs. 0 from 8 CON cows) and retained placenta (RP; 4 from 8 LPS cows vs. 0 from 8 CON cows). In addition, the discriminant analysis differently clustered the cow responses within LPS group, each corresponding to LDA, RP, and the cows displaying no clinical health problems (LPS-NO). The
\end{abstract}

Received January 19, 2011.

Accepted June 30, 2011

${ }^{1}$ Corresponding author: burim.ametaj@ualberta.ca stepwise selection procedure of the best discriminant variables revealed that plasma Ca and anti-LPS IgG, as well as glucose and cortisol, were the best discriminating variables for cows affected by LDA, whereas NEFA and cholesterol better discriminated for cows affected by RP. This analysis also revealed that the cluster of plasma variables including plasma $\mathrm{Cu}$, SAA, BHBA, and anti-LPS IgA were the best discrimination for the LPS-NO group. In conclusion, our results indicate a role of endotoxemia, during the periparturient period, in development of metabolic and immune disturbances, as well as in the etiopathology of displaced abomasum and retained placenta in dairy cows.

Key words: endotoxemia, metabolic disease, innate immunity, periparturient dairy cow

\section{INTRODUCTION}

The transition period in dairy cows is marked by important metabolic and immunological changes imposed primarily by endocrine and nutritional events associated with parturition and the onset of lactation. This period is also characterized by a high incidence of metabolic diseases. Despite significant progress made during the last decades in the areas of breeding and nutritional management that resulted in enhanced production capacity of dairy cattle, the incidence of metabolic diseases including left displaced abomasum (LDA) and retained placenta (RP) in dairy cows is still high (Kimura et al., 2002; LeBlanc et al., 2005; Goff, 2006). The decline in immune status around parturition and the high incidences of LDA and RP negatively affect herd health, fertility, and milk production (Kimura et al., 2002; LeBlanc et al., 2005). The underlying mechanism(s) of the aforementioned metabolic diseases are not well understood yet, which hampers development of effective prophylactic strategies.

Recently, several lines of evidence have shown that cows experiencing an acute phase response (APR) around parturition have greater odds of developing metabolic diseases (Ametaj et al., 2005; Loor et al., 
2006; Bionaz et al., 2007). This suggests that the presence of inflammation around parturition, or its causal agent, is involved in the etiopathology of metabolic diseases postpartum (Bertoni et al., 2008; Ametaj et al., 2010). Pioneering work conducted by Nagaraja et al. (1978) has shown that feeding feedlot cattle diets rich in rapidly fermentable carbohydrates results in the accumulation of large amounts of LPS in the rumen fluid. Recent research conducted by our team and others has demonstrated that systemic APR is activated by translocation of LPS (Emmanuel et al., 2008; Khafipour et al., 2009). The latter, also known as endotoxin, is a cell wall component of all gram-negative bacteria and a highly proinflammatory compound released in the rumen fluid in response to high-grain feeding (Emmanuel et al., 2008; Ametaj et al., 2009a; Khafipour et al., 2009). Feeding high amounts of grain to early lactating cows is a nutritional event commonly observed at the onset of lactation to support the dairy cow's high energy needs.

The experimentally induced endotoxemia, or the endotoxin released in the rumen due to the feeding of large amounts of cereal grains, has been shown to be associated with perturbations of plasma minerals (Waldron et al., 2003a; Zebeli et al., 2010) and endocrine mediators responsible for regulation of energy and lipid metabolism (López-Soriano and Williamson, 1994; Waldron et al., 2003b; Zebeli and Ametaj, 2009). Interestingly, during the periparturient period, cows with LDA often suffer from concurrent diseases such as rumen acidosis, fatty liver, RP, endometritis, or mastitis (LeBlanc et al., 2005), which in turn are potential sources of endotoxin and metabolic endotoxemia.

Although much is known about metabolic and immune responses to single-dose challenges with LPS, information is lacking on the role of chronic metabolic endotoxemia on metabolic health during the periparturient period in dairy cows. Metabolic disorders related to endotoxin exposure are an important and challenging health-related issue at the onset of lactation in dairy cattle (Andersen, 2003; Ametaj et al., 2010). Our hypothesis was that periparturient chronic endotoxemia might be involved in alterations of metabolic and immune responses as well as in the etiopathology of metabolic diseases commonly observed in transition dairy cows such as LDA and RP.

To test our hypothesis, we induced intermittent endotoxemia by infusing increasing doses of LPS, simulating a progressive endotoxemia during the transition period. Therefore, the aim of this study was to determine the effects of intermittent i.v. administration of LPS on metabolic, immune, and mineral responses and on metabolic health status and production performance of periparturient dairy cows. Cows in the experiment were monitored for metabolic health status and an array of plasma variables related to carbohydrate, lipid, and mineral metabolism as well as for innate immune responses.

\section{MATERIALS AND METHODS}

\section{Animals and Treatments}

Sixteen clinically healthy (i.e., free of infectious or metabolic diseases), pregnant Holstein dairy cows (in average: 1.6 lactations) at the Dairy Research and Technology Centre, University of Alberta, were included in this longitudinal study. All experimental procedures were approved by the University of Alberta Animal Care and Use Committee for Livestock, and animals were cared for in accordance with the guidelines of the Canadian Council on Animal Care (1993). At 14 d before the expected day of calving (i.e., $-14 \mathrm{~d}$ ), cows were blocked by parity and anticipated day of calving, and were randomly allocated to 1 of 2 different treatment groups, with 8 cows each, according to a randomized block design. The 8 cows assigned to i.v. saline $(0.9 \%$ wt/vol $\mathrm{NaCl}$ ) infusion constituted the control group $(\mathbf{C O N})$. The other 8 cows pertaining to the LPS group received i.v. infusion of LPS (Escherichia coli O111:B4; Sigma-Aldrich, Mississauga, Ontario, Canada). Three increasing doses of LPS dissolved in sterile saline solution $(0.9 \% \mathrm{wt} / \mathrm{vol} \mathrm{NaCl})$ were administered to the treatment cows before and after parturition. The doses and the schedule of LPS administration were as follows: (1) $0.01 \mu \mathrm{g}$ of LPS $/ \mathrm{kg}$ of BW twice on $\mathrm{d}-14$ and -10 ; (2) $0.05 \mu \mathrm{g}$ of LPS $/ \mathrm{kg}$ of BW twice on $\mathrm{d}-7$ and -3 ; and (3) $0.1 \mu \mathrm{g}$ of LPS $/ \mathrm{kg}$ of BW twice on $\mathrm{d} 3$ and 7 postpartum. Increasing doses of LPS were used to simulate a model of a progressive endotoxemia similar to conditions of an endotoxemic insult occurring often during the transition period due to major changes taking place in the diet and the occurrence of infectious peripartal diseases elicited by gram-negative bacteria.

The experiment lasted 6 wk (i.e., 2 wk before and 4 wk after parturition) and cows were housed in tie stalls with free access to water throughout the experiment. Two hours before the LPS administration, cows were restrained in separate pens adjacent to each other, and the infusion area was washed and sterilized with $70 \%$ ethyl alcohol. To facilitate the i.v. administration and blood sampling, an indwelling catheter was introduced into the jugular vein, as described previously (Zalkovic et al., 2001). The amount of LPS was dissolved in 100 $\mathrm{mL}$ of sterile saline solution $(0.9 \% \mathrm{wt} / \mathrm{vol} \mathrm{NaCl})$ and infused into the jugular vein via the catheter. The cows of the CON group were administered the same amount of sterile saline solution $(0.9 \% \mathrm{wt} / \mathrm{vol} \mathrm{NaCl})$ according 
Table 1. Ingredients and chemical composition of TMR offered to experimental cows during the prepartum and lactation period

\begin{tabular}{|c|c|c|}
\hline Item & Prepartum & Postpartum \\
\hline \multicolumn{3}{|l|}{ Ingredients, $\%$ of DM } \\
\hline Barley grain, steam rolled & 16.4 & 29.8 \\
\hline Corn grain, steam rolled & 4.0 & 7.9 \\
\hline Grass hay & 10 & - \\
\hline Alfalfa hay & - & 9.6 \\
\hline Alfalfa silage & - & 19.9 \\
\hline Barley silage & 60.2 & 20.3 \\
\hline Dairy supplement ${ }^{1}$ & 1.1 & 12.5 \\
\hline Animate $^{2}$ & 4.8 & - \\
\hline Molasses beet sugar & 0.6 & - \\
\hline Vegetable oil & 0.7 & - \\
\hline Limestone & 1.5 & - \\
\hline Vitamin E $(5,000 \mathrm{IU} / \mathrm{kg})$ & 0.4 & - \\
\hline Vitamin $\mathrm{D}_{3}(500,000 \mathrm{IU} / \mathrm{kg})$ & 0.2 & - \\
\hline \multicolumn{3}{|c|}{ Energy and nutrient composition, \% of DM unless stated } \\
\hline $\mathrm{DM}, \%$ & 43.7 & 54.0 \\
\hline $\mathrm{NE}_{\mathrm{L}}, \mathrm{Mcal} / \mathrm{kg}$ of $\mathrm{DM}$ & 1.55 & 1.71 \\
\hline NDF & 45.3 & 27.8 \\
\hline $\mathrm{ADF}$ & 26.7 & 15.7 \\
\hline $\mathrm{NFC}^{3}$ & 30.3 & 42.1 \\
\hline Ether extract & 3.7 & 4.6 \\
\hline $\mathrm{CP}$ & 14.7 & 18.1 \\
\hline $\mathrm{Ca}$ & 0.94 & 1.11 \\
\hline $\mathrm{P}$ & 0.4 & 0.5 \\
\hline $\mathrm{K}$ & 1.9 & 1.5 \\
\hline $\mathrm{Mg}$ & 0.4 & 0.4 \\
\hline
\end{tabular}

${ }^{1}$ Supplied by Champion Feed Services Ltd. (Barrhead, AB, Canada); contained malt sprouts (0.1\%), canola fines $(12.5 \%)$, canola meal $(6.0 \%)$, corn gluten $(25.0 \%)$, fish herring meal $(10.0 \%)$, peas ground $(4.0 \%)$, soybean meal $(10.0 \%)$, canola oil/soy oil $(3.0 \%)$, canola oil $(3.0 \%)$, Megalac $(7.5 \%)$, calcium carbonate $(1.5 \%)$, magnesium oxide $58 \%(1.6 \%)$, dicalcium phosphate $(5.2 \%)$, salt potash $(3.1 \%)$, sodium bicarbonate $(5.0 \%)$, vitamin E $500(0.03 \%)$, and CFS dairy premix (1.6\%).

${ }^{2}$ Anionic mineral supplemented for nonlactating dairy cows, contained $\mathrm{CP}$ (min, 35.0\%), equivalent $\mathrm{CP}$ from non protein sources (max, 25\%), calcium (actual, 1.10\%), magnesium (actual, 3.65\%), sulfur (actual, $4.65 \%$ ), chlorine (actual, $11.90 \%)$, and $(\mathrm{Na}+\mathrm{K})-(\mathrm{Cl}+\mathrm{S})$ (actual, $-6,047 \mathrm{mEq} / \mathrm{kg}$ ); Granco Minerals Inc. (Disputanta, VA).

${ }^{3} \mathrm{NFC}$ was calculated as $100-[(\mathrm{NDF}-\mathrm{NDFCP})+\mathrm{CP}+$ ether extract + ash $](\mathrm{NRC}, 2001)$.

to the aforementioned schedule of the LPS administration. The saline or LPS-saline solution was introduced at a rate of $2 \mathrm{~mL} / \mathrm{min}$ (approximately 50-min infusion time).

The cows were fed once daily at $0800 \mathrm{~h}$ and milked twice at 0500 and $1530 \mathrm{~h}$ in their stalls. All cows were fed the same close-up diet starting 3 wk before the day of parturition. After parturition, cows were gradually switched during the first $7 \mathrm{~d}$ to a fresh-lactation diet (Table 1). All diets were formulated to meet or exceed the nutrient requirements of dry and early lactating cows according to NRC (2001) guidelines. Daily ration was offered as TMR for ad libitum intake to allow approximately $5 \%$ feed refusals throughout the experiment. According to the farm management practice, when feed intake of the cows on a previous day decreased below $10 \mathrm{~kg} / \mathrm{d}$, a flat dose of $500 \mathrm{~mL}$ of propylene glycol (Vétoquinol N.-A. Inc., Lavaltrie, Quebec, Canada) was orally administered to each cow on the next morning.

\section{Monitoring the Clinical Health Status of the Cows}

Cows were supervised daily by the herd veterinary technician for signs of clinical disease and distress, and all diseases were recorded for each cow throughout the entire experimental period. Milk yield, feed intake, and rectal temperature were also recorded daily. When the experimental cows drastically decreased their feed intake and milk production or displayed clinical signs of disease, they were submitted to a specialized veterinary inspection. The cows were moved to the maternity barn on the day of parturition, and the postcalving process was closely monitored.

Four out of 8 cows in the LPS group failed to lose their fetal membranes within $24 \mathrm{~h}$ of calving, a pathological condition defined as retained placenta (Kimura et al., 2002). According to the farm veterinary protocol, cows with RP were treated with Tetrabol (Vétoquinol N.-A. Inc.) in the uterine cavity. Two other cows in the LPS group were diagnosed with LDA during the second week postpartum. This diagnosis was confirmed 
after surgery via right flank laparotomy under local analgesia; the abomasal body was displaced to the left dorsal abdominal quadrant between the left body wall and the rumen. After abdominal exploration and confirmation of LDA by the specialized veterinarian, the abomasum was decompressed and returned to its normal anatomical position. To ensure a rapid and smooth recovery from the surgery, the cows affected by LDA were administered propylene glycol (Vétoquinol N.-A. Inc.) at $250 \mathrm{~mL}$ twice a day for the first $3 \mathrm{~d}$, and $125 \mathrm{~mL}$ for another $2 \mathrm{~d}$, as well as $50 \mathrm{~mL}$ of Procillin (penicillin G procaine, Bimeda-MTC Animal Health Inc., Cambridge, Ontario, Canada) once a day for $3 \mathrm{~d}$. The remaining cows in the LPS group did not show any clinical sign of disease, and neither did any of the cows in the CON group.

\section{Blood Sampling}

Blood samples were collected from the tail vein shortly before the infusions of saline or LPS at $0730 \mathrm{~h}$. Multiple blood samples were collected pre- and postpartum on d $-14,-10,-7,-3,3,7,14,21$, and 28. Sodium heparin or EDTA 10-mL Vacutainer tubes (Becton Dickinson, Franklin Lake, NJ) were used to collect blood samples. Immediately after collection, blood samples were stored on ice, and plasma was separated within $20 \mathrm{~min}$ of collection by centrifuging at $3,000 \times g$ at $4^{\circ} \mathrm{C}$ for 20 min (Rotanta $460 \mathrm{R}$ centrifuge, Hettich Zentrifugan, Tuttlingen, Germany). Plasma samples were stored at $-20^{\circ} \mathrm{C}$ until analysis.

\section{Sample Analyses}

Plasma Acute Phase Proteins. Concentrations of the acute phase proteins (APP) serum amyloid A (SAA), LPS-binding protein (LBP), and haptoglobin $(\mathbf{H p})$ in plasma were determined by commercially available ELISA kits according to methods described previously (Emmanuel et al., 2008). In brief, plasma samples for SAA and LBP analyses were initially diluted 1:500, and samples with optical density values above the range of the standard curve were diluted further (1:400 or 1:250) and reanalyzed. No dilution of plasma was necessary for measurement of Hp. All samples were tested in duplicate and the optical density values were read on a microplate spectrophotometer (Spectramax 190, Molecular Devices Corp., Sunnyvale, CA) at 450 $\mathrm{nm}$. The intraassay variation of all APP assays was controlled by CV limits $\leq 10 \%$. The minimum detection limits for SAA, LBP, and Hp assays were 18.8, 1.0, and $0.25 \mathrm{ng} / \mathrm{mL}$, respectively.

Plasma IgA, IgG, and IgM. The $\operatorname{IgA}, \operatorname{IgG}$, and IgM specific for LPS were measured using commercially available EndoCab ELISA kits (Cell Science, Canton,
MA), which were developed to determine the crossreactive antibodies to the core region of LPS (Barclay, 1995). The EndoCab ELISA is solid-phase ELISA based on the sandwich principle, and has a working time of $2.5 \mathrm{~h}$. According to the manufacturer's recommendations, $\operatorname{IgA}$ and $\operatorname{IgG}$ were measured in plasma samples diluted 200 times and IgM in plasma samples diluted 100 times. The color developed is proportional to the amount of anti-LPS core antibodies present in the sample. Absorbance was measured at $450 \mathrm{~nm}$ with a spectrophotometer (Spectramax 190, Molecular Devices Corp.). The detection limits of $\operatorname{IgG}$, IgM, and $\operatorname{IgA}$ EndoCab antibodies were, respectively, 0.125, 0.055, and 0.156 median units $(\mathrm{MU}) / \mathrm{mL}$, and the intraassay CV was $<10 \%$.

Plasma Metabolites and Minerals. Methods used for measurement of glucose, BHBA, NEFA, cholesterol, and lactate concentrations in the plasma were described previously in detail (Ametaj et al., 2009b). In addition, the methods for quantitation of plasma minerals were as described by Zebeli et al. (2010). Plasma insulin was measured by commercially available bovine ELISA kit supplied by Mercodia AB (Uppsala, Sweden). This procedure involved a solid-phase, 2 -site enzyme immunoassay. It is based on the direct sandwich technique in which 2 monoclonal antibodies are directed against separate antigenic determinants on the insulin molecule. During incubation, insulin in the sample reacts with peroxidase-conjugated antiinsulin antibodies and anti-insulin antibodies bound to the micro-titration wells. After simple washing that removes unbound enzyme-labeled antibody, the bound conjugate is detected by reaction with $3,3^{\prime}-5,5^{\prime}$-tetramethylbenzidine. The reaction is stopped by the addition of stop solution giving a colorimetric endpoint that can be read spectrophotometrically (Spectramax 190, Molecular Devices Corp.) at $450 \mathrm{~nm}$. The detection limit of the assay was $0.025 \mu \mathrm{g} / \mathrm{L}$, and the intraassay CV of the assay was $<10 \%$.

Plasma cortisol was measured by commercially available EIA kit (Diagnostic Systems Laboratories Inc., Webster, TX). The procedure involved the basic principle of enzyme immunoassay with competition between an unlabeled antigen and an enzyme-labeled antigen for a fixed number of antibody-binding sites. The amount of enzyme-labeled antibody is inversely proportional to the concentration of the unlabeled analyte present in the solution. Unbound materials were removed by decanting and washing the wells. All samples were in duplicate. The optical density was measured at 450 $\mathrm{nm}$ in microplate reader (Spectramax 190, Molecular Devices Corp.), and concentration was calculated by using a 4-parameter curve fit. The detection limit of the assay was $0.3 \mu \mathrm{g} / \mathrm{dL}$. 


\section{Statistical Analyses}

A multivariate discriminant analysis with JMP software (version 8.0.1, SAS Institute Inc., Cary, NC) was initially conducted to determine potential differences in the metabolic and immunological responses of cows in relation to their health status. The discrimination model was developed using the linear discriminant method of the JMP (version 8.0.1, SAS Institute Inc., Cary, NC). The latter is a supervised classification technique, where the number of categories and the samples that belong to each category were previously defined. The LPS-treated cows were classified in 3 categories according to health status: the group of cows affected by RP: LPS-RP; the group of cows affected by LDA: LPS-LDA; and the group of cows showing no clinical signs of disease: LPS-NO. The classification of health status did not differentiate among the CON cows, because they remained clinically healthy throughout the experiment. The linear discriminant analysis shows the similarities and differences among the data sets (i.e., health status classes). The data sets exhibiting similarities are clustered together and those that are different are placed further apart in the canonical axes 1 and 2 .

The parametric analysis of the data consisted of ANOVA using the MIXED procedure of SAS (version 9.1.3; SAS Institute Inc., Cary, NC). An overall model was fitted to take into consideration the fixed effects of sampling time, treatment, and their 2-way interactions. In addition, another model was fitted to account for the fixed effects of health status of the cows (i.e., LPSLDA, LPS-RP, and LPS-NO), nested within treatment, and its 2-way interaction with sampling time.

In both ANOVA tests, measurements taken at different times on the same cow were considered as repeated measures. The variance-covariance structure of the repeated measures was modeled separately for each response variable according to the lowest values of the fit statistics based on the Bayesian information criteria and an appropriate structure was fitted. Degrees of freedom were approximated by the method of Kenward-Roger $(\mathrm{ddfm}=\mathrm{kr})$. Least squares means and the respective SEM were computed. Significance was declared at $P \leq 0.05$, and a tendency was considered up to $0.05<P \leq 0.10$.

\section{RESULTS}

\section{Outcome of the Discriminant Analysis}

The linear discriminant analysis revealed that intermittent endotoxemia separated the responses obtained not only in 2 different major clusters respective to the treatment groups (i.e., CON and LPS), but also in regard to the health status of cows within the LPS group. Thus, the discriminant analysis differently clustered the cow responses within the LPS group, each corresponding to LDA, RP, and the cows displaying no clinical health symptoms (Figure 1). In terms of the dissimilarity among the response clusters obtained, this analysis showed that multivariate means and the corresponding $50 \%$ normally distributed ellipses pertaining to CON and LPS-LDA groups differed from each other, relative to canonical axis 1 , which indicates the greatest dissimilarity among the 4 clusters obtained. This analysis also showed that the responses of LPS-NO cows were clustered apart from those of the other groups, including the saline-infused clinically healthy cows. Interestingly, the discriminant analysis demonstrated greater discrimination between LPS-NO and LPS-RP, but greater similarity between the latter group and $\mathrm{CON}$, which indicates stronger similarity between the responses obtained from cows affected by $\mathrm{RP}$ and the controls.

The stepwise selection procedure of the best discriminant variables also revealed that plasma $\mathrm{Ca}$ and antiLPS IgG as well as glucose and cortisol were the best discriminating variables for LPS-LDA cows, whereas NEFA and cholesterol better discriminated for LPSRP. This analysis also indicated that the cluster of plasma variables including plasma $\mathrm{Cu}$, SAA, BHBA, and anti-LPS IgA were the best discrimination for LPS-NO group (Figure 1).

\section{Performance and Changes of Plasma Variables}

Results of the marginal changes revealed by ANOVA for the 19 variables measured are presented in Tables 2 and 3 . For all variables affected by treatment $\times$ sampling time interaction as well as by health status and its interaction with sampling time, nested within treatment, the cell LSM were computed; results are shown in Figures 2 to 5.

Data showed that experimental endotoxemia induced changes in feed intake and milk production (Table 2). For example, ANOVA revealed that feed intake of the LPS-infused cows was lower during the postparturient period (Figure 2a), and this response was reflected by a decreased milk yield of the cows (Figure 2b). The ANOVA also showed that LPS-treated cows affected by LDA had the lowest feed intake and milk production, and the latter variable did not recover until termination of the experiment (i.e., $28 \mathrm{~d}$ postpartum).

Data showed that the concentration of cholesterol in the plasma was affected by repeated i.v. infusion of LPS (Table 2). Interestingly, the LPS-treated cows had lower plasma cholesterol $(P<0.01)$, and the LPS-NO group showed the lowest concentration of cholesterol 


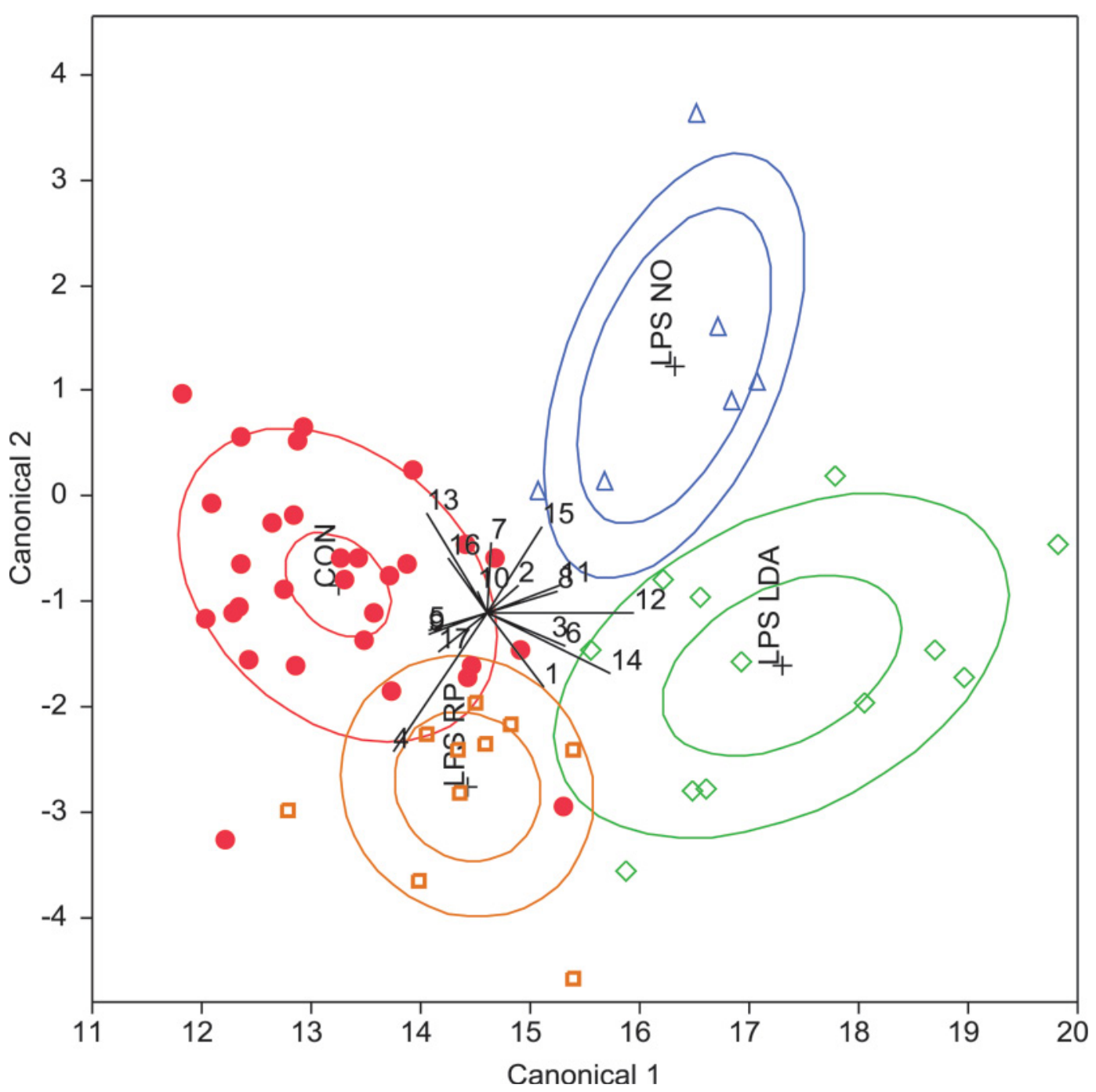

Figure 1. Linear discriminant analysis of the determinant plasma variables in periparturient dairy cows infused i.v. with saline (CON, or LPS. The LPS cows were classified as affected by left displaced abomasum (LPS-LDA, $\diamond)$ or retained placenta (LPS-RP, $\square$ ), or were clinically healthy (LPS-NO, $\Delta$ ). The sign $(+)$ indicates multivariate mean of each independent variable (i.e., treatments), and the size of the inner ellipse indicates the confidence limits of the mean, whereas the outer ellipses show the normally distributed $50 \%$ contours. The distance between the treatments in the canonical axis 1 and 2 reflects their dissimilarity. The straight lines are indicative of dependent variables included in the analysis, and their length and angles between them are functions of the relative effects of independent variables. Numbers indicate the following plasma variables: $1=$ NEFA; $2=$ BHBA; $3=$ glucose; $4=$ cholesterol; $5=$ lactate; $6=$ cortisol; $7=$ insulin; $8=$ serum amyloid A; $9=$ LPSbinding protein; $10=$ haptoglobin; $11=$ anti-LPS IgA; $12=$ anti-LPS IgG; $13=$ anti-LPS IgM; $14=$ calcium; $15=$ copper; $16=$ iron; $17=$ zinc. Color version available in the online PDF.

around parturition within the latter group (Figure 3a). Although LPS infusion did not affect the overall concentration of BHBA in the plasma, the ANOVA indicated an interaction between health status within LPS group and sampling time. As illustrated in Figure 3b, the LPS-LDA cows showed greater plasma BHBA on d -10 and 3 , whereas in the LPS-RP cows plasma BHBA peaked at $14 \mathrm{~d}$ postpartum. Other data showed that LPS infusion increased the concentration of cortisol in plasma (Table 2). In particular, cows affected by LDA demonstrated the greatest plasma cortisol both before and after the parturition (Figure 3c). In addition, plasma variables including insulin, glucose, lactate, and NEFA were not affected by the LPS infusion, although the latter 2 variables were affected by sampling day (Table 2). Thus, plasma NEFA and lactate increased in both groups during the first week after parturition and then declined, reaching the lowest levels at $4 \mathrm{wk}$ postpartum.

Data also showed that i.v. infusion of LPS was not associated with changes in the overall responses of plasma minerals (Table 2). However, the ANOVA distinguished 
Table 2. Results of feed intake, milk yield, and selected plasma variables in periparturient Holstein cows administered i.v. saline (CON) or LPS $(\mathrm{LSM} \pm \mathrm{SEM} ; \mathrm{n}=8)$

\begin{tabular}{|c|c|c|c|c|c|c|c|c|}
\hline \multirow[b]{2}{*}{ Variable } & \multicolumn{2}{|c|}{ Treatment $^{1}$} & \multirow[b]{2}{*}{ SEM } & \multicolumn{5}{|c|}{ Effect, ${ }^{2} P$-value } \\
\hline & $\mathrm{CON}$ & LPS & & $\mathrm{T}$ & D & $\mathrm{T} \times \mathrm{D}$ & $\mathrm{S}(\mathrm{T})$ & $\begin{array}{l}\mathrm{S}(\mathrm{T}) \\
\times \mathrm{D}\end{array}$ \\
\hline Milk yield, $\mathrm{kg} / \mathrm{d}$ & 29.5 & 22.4 & 1.44 & $<0.01$ & 0.01 & 0.30 & $<0.01$ & 0.01 \\
\hline \multicolumn{9}{|c|}{ Plasma metabolites and hormones } \\
\hline Cholesterol, mg/dL & 123 & 96.4 & 5.59 & $<0.01$ & $<0.01$ & $<0.01$ & $<0.01$ & $<0.01$ \\
\hline BHBA, mmol/L & 0.87 & 0.91 & 0.08 & 0.76 & $<0.01$ & 0.42 & 0.22 & 0.03 \\
\hline Lactate, $\mathrm{mmol} / \mathrm{L}$ & 3.22 & 3.02 & 0.27 & 0.61 & $<0.01$ & 0.19 & 0.68 & 0.93 \\
\hline NEFA, mEq/L & 0.55 & 0.59 & 0.06 & 0.65 & $<0.01$ & 0.63 & 0.54 & 0.20 \\
\hline Cortisol, $\mu \mathrm{g} / \mathrm{dL}$ & 3.49 & 6.78 & 0.99 & 0.03 & $<0.01$ & 0.39 & 0.01 & 0.01 \\
\hline \multicolumn{9}{|l|}{ Plasma minerals } \\
\hline Calcium, mg/dL & 10.5 & 10.4 & 0.22 & 0.76 & $<0.01$ & 0.10 & 0.72 & 0.05 \\
\hline Zinc, mg/L & 1.75 & 1.83 & 0.35 & 0.87 & 0.03 & 0.09 & 0.45 & 0.44 \\
\hline
\end{tabular}

${ }^{1} \mathrm{LPS}$ was i.v. infused at $0.01 \mu \mathrm{g} / \mathrm{kg}$ of BW on $\mathrm{d}-14$ and -10 ; at $0.05 \mu \mathrm{g} / \mathrm{kg}$ of BW on $\mathrm{d}-7$ and -3 , and at $0.1 \mu \mathrm{g} / \mathrm{kg}$ of BW on $\mathrm{d} 3$ and 7 . Sterile saline solution was infused at the same day with the LPS administration.

${ }^{2}$ Effects of i.v. treatment $(\mathrm{T})$, sampling day around parturition $(\mathrm{D} ;-14,-10,-7,-3,3,7,14,21$, and $28 \mathrm{~d})$, their two-way interaction $(\mathrm{T} \times \mathrm{D})$, health status of cows nested within treatment $[\mathrm{S}(\mathrm{T})$; LPS-treated cows affected by left displaced abomasum, $\mathrm{n}=2$; LPS-treated cows affected by retained placenta, $\mathrm{n}=4$; LPS-treated cows being clinically healthy, $\mathrm{n}=2$; CON $=$ clinically healthy cows, $\mathrm{n}=8]$, and its resulting two-way interaction with the sampling day $[\mathrm{S}(\mathrm{T}) \times \mathrm{D}]$.

an interaction between health status and sampling day for plasma $\mathrm{Ca}$, and an effect of health status on plasma $\mathrm{Cu}$. Interestingly, cows affected by LDA showed greater concentrations of $\mathrm{Ca}$ in plasma before parturition, but lower concentrations after parturition (Figure 4a). Furthermore, this analysis indicated that cows pertaining to the LPS-NO group had greater concentrations of plasma $\mathrm{Cu}$ starting at $-10 \mathrm{~d}$ before parturition (Figure 4b).

Results of the overall ANOVA indicated that repeated LPS administration did not affect concentrations of SAA, LBP, and Hp in the plasma (Table 3).
Data showed that sampling time affected plasma concentration of SAA and $\mathrm{Hp}(P \leq 0.05)$. The plasma concentrations of the latter $2 \mathrm{APP}$ were greater in both groups of cows around parturition and then declined to lower levels starting from d 10 until d 28 after calving. Furthermore, results indicated that cows pertaining to the LPS-LDA and LPS-RP groups had greater concentrations of Hp in plasma on d 3 postpartum, whereas those of the LPS-NO group on $\mathrm{d}-14$ and 14 (Figure $5 a)$. The overall ANOVA revealed that cows treated with LPS had greater concentrations of anti-LPS IgG and a tendency to increase anti-LPS IgA, whereas the

Table 3. Variables of innate immunity in periparturient Holstein cows administered i.v. saline (CON) or LPS $(\mathrm{LSM} \pm \mathrm{SEM} ; \mathrm{n}=8)$

\begin{tabular}{|c|c|c|c|c|c|c|c|c|}
\hline \multirow[b]{2}{*}{ Variable $^{1}$} & \multicolumn{2}{|c|}{ Treatment $^{2}$} & \multirow[b]{2}{*}{ SEM } & \multicolumn{5}{|c|}{ Effect, ${ }^{3} P$-value } \\
\hline & $\mathrm{CON}$ & LPS & & $\mathrm{T}$ & $\mathrm{D}$ & $\mathrm{T} \times \mathrm{D}$ & $\mathrm{S}(\mathrm{T})$ & $\begin{array}{l}\mathrm{S}(\mathrm{T}) \\
\times \mathrm{D}\end{array}$ \\
\hline $\mathrm{SAA}, \mu \mathrm{g} / \mathrm{mL}$ & 28.0 & 28.5 & 3.66 & 0.93 & 0.05 & 0.99 & 0.54 & 0.15 \\
\hline $\mathrm{LBP}, \mu \mathrm{g} / \mathrm{mL}$ & 52.9 & 38.6 & 8.65 & 0.27 & 0.10 & 0.64 & 0.76 & 0.96 \\
\hline $\mathrm{Hp}, \mathrm{mg} / \mathrm{mL}$ & 0.69 & 0.98 & 0.13 & 0.12 & 0.03 & 0.91 & 0.13 & 0.05 \\
\hline $\operatorname{IgA}, \mathrm{MU}^{4} / \mathrm{mL}$ & 0.056 & 0.061 & 0.002 & 0.09 & 0.77 & 0.82 & 0.06 & 0.93 \\
\hline
\end{tabular}

${ }^{1} \mathrm{SAA}=$ serum amyloid A; LBP = LPS-binding protein; Hp = haptoglobin; IgA, IgG, IgM = anti-LPS immunoglobulins A, G, and M, respectively.

${ }^{2} \mathrm{LPS}$ was i.v. infused at $0.01 \mu \mathrm{g} / \mathrm{kg}$ of BW on $\mathrm{d}-14$ and -10 ; at $0.05 \mu \mathrm{g} / \mathrm{kg}$ of BW on $\mathrm{d}-7$ and -3 , and at $0.1 \mu \mathrm{g} / \mathrm{kg}$ of BW on $\mathrm{d} 3$ and 7 . Sterile saline solution was infused at the same day with the LPS administration.

${ }^{3}$ Effects of i.v. treatment $(\mathrm{T})$, sampling day around parturition $(\mathrm{D} ;-14,-10,-7,-3,3,7,14,21$, and $28 \mathrm{~d})$, their two-way interaction $(\mathrm{T} \times \mathrm{D})$, health status of cows nested within treatment $[\mathrm{S}(\mathrm{T})$; LPS-treated cows affected by left displaced abomasum, $\mathrm{n}=2$; LPS-treated cows affected by retained placenta, $\mathrm{n}=4$; LPS-treated cows being clinically healthy, $\mathrm{n}=2$; CON $=$ clinically healthy cows, $\mathrm{n}=8]$, and its resulting two-way interaction with the sampling day $[\mathrm{S}(\mathrm{T}) \times \mathrm{D}]$.

${ }^{4}$ Median units. 

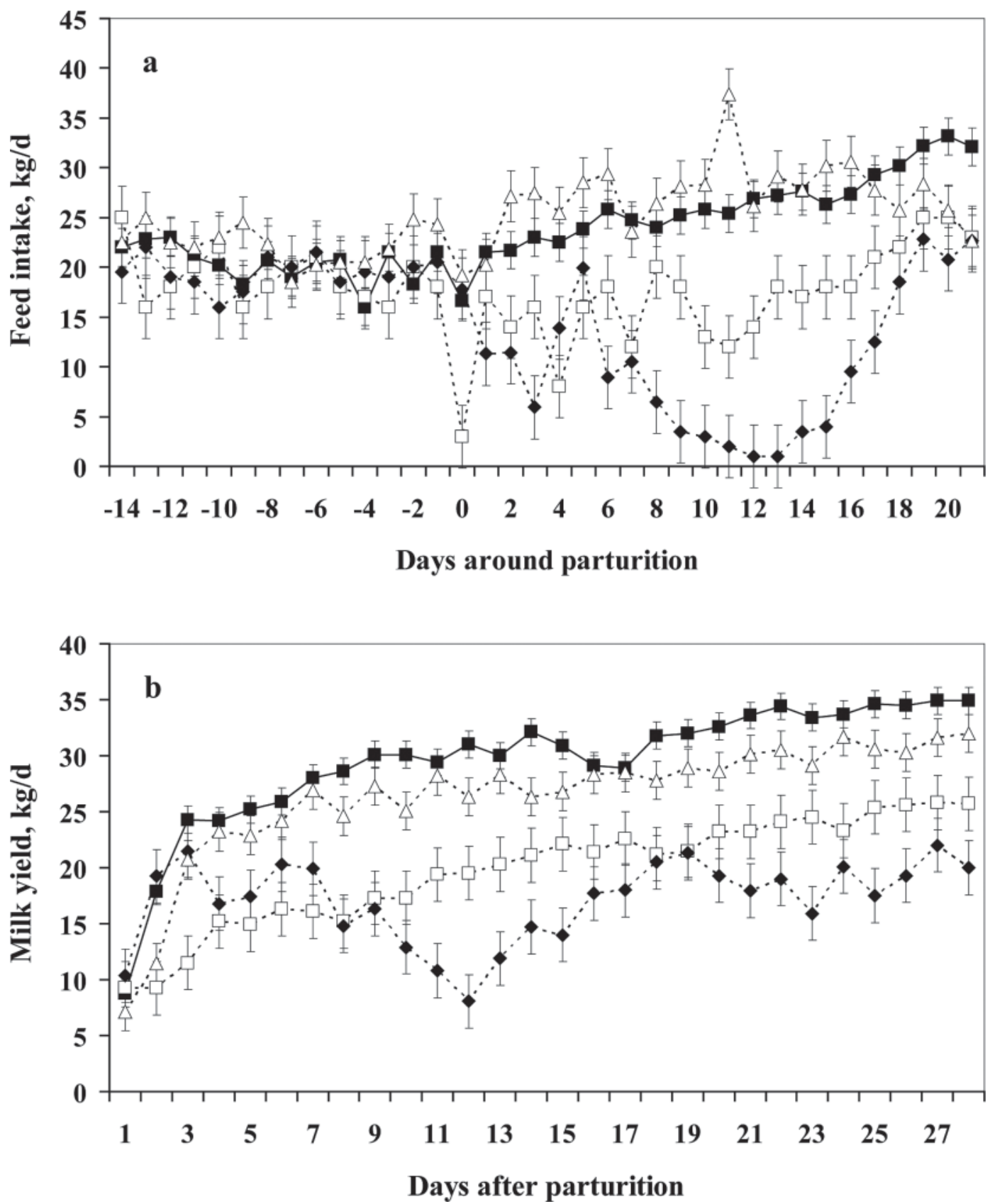

Figure 2. Data of feed intake (a) and milk production (b) in periparturient dairy cows infused i.v. with saline (ם) or LPS; the LPS-treated cows were classified as affected by left displaced abomasum $(\bullet)$ or retained placenta $(\triangle)$, or were clinically healthy ( $\square$ ). The LPS was i.v. infused at $0.01 \mu \mathrm{g} / \mathrm{kg}$ of BW on $\mathrm{d}-14$ and -10 ; at $0.05 \mu \mathrm{g} / \mathrm{kg}$ of BW on $\mathrm{d}-7$ and -3 , and at $0.1 \mu \mathrm{g} / \mathrm{kg}$ of BW on d 3 and 7 ; sterile saline solution was infused on the same day as LPS administration.

concentration of anti-LPS IgM was decreased in the plasma of LPS-treated cows (Table 3). The control cows demonstrated greater titers of IgM antibodies in the plasma particularly before and shortly after parturition (Figure $5 \mathrm{~b}$ ), whereas the titers of IgG antibodies were lower in the control cows during the time after parturition (Figure 5c).

\section{DISCUSSION}

Productive Performance and the Incidence of LDA and RP During Induced Endotoxemia

In this study, we demonstrated that experimentally induced intermittent endotoxemia around parturition impaired the productive performance of dairy cows and 

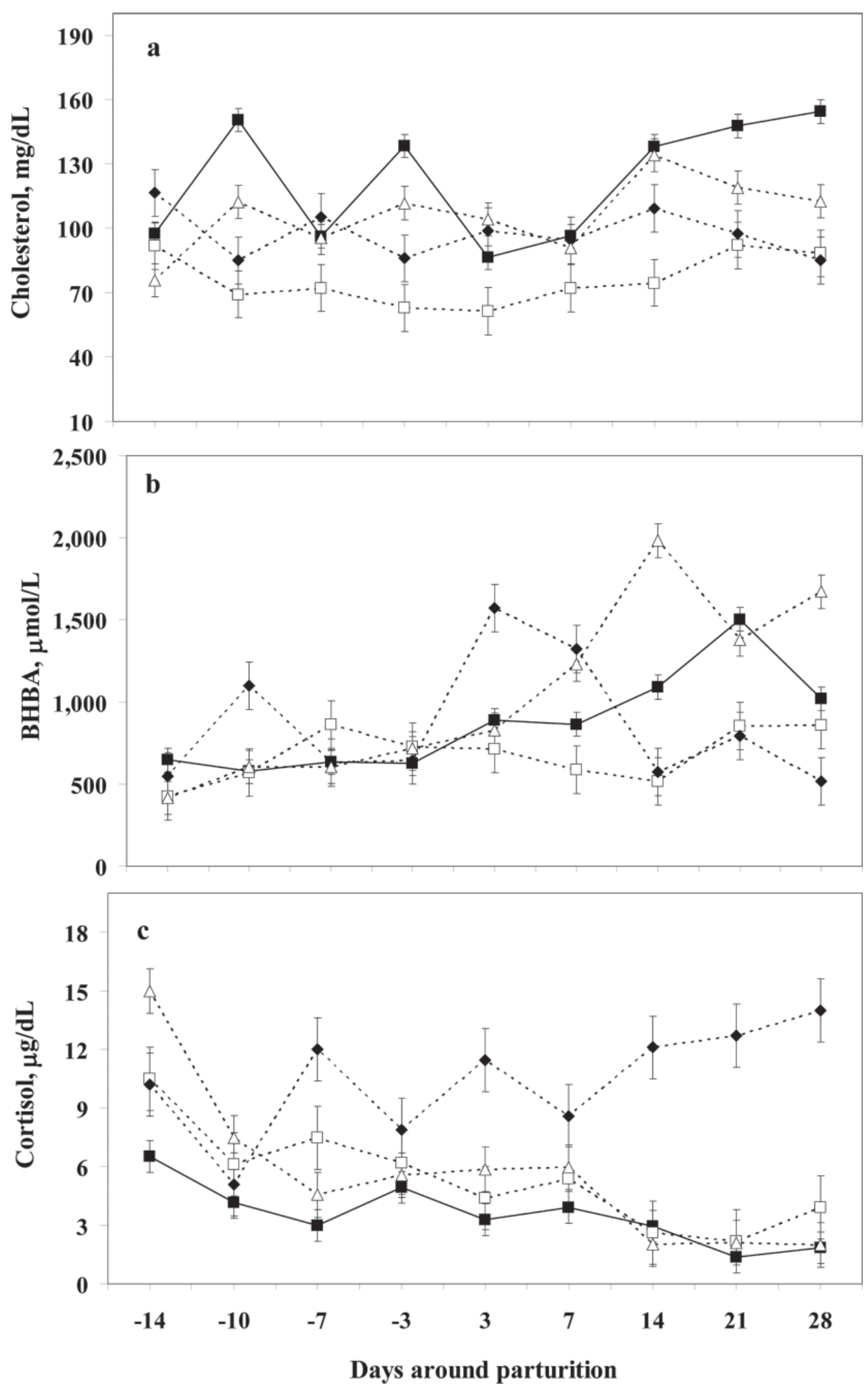

Figure 3. Data of cholesterol (a), BHBA (b), and cortisol (c) in the plasma of periparturient dairy cows infused i.v. with saline (ם) or LPS; the LPS-treated cows were classified as affected by left displaced abomasum $(\bullet)$ or retained placenta $(\Delta)$, or were clinically healthy $(\square)$. The LPS was i.v. infused at $0.01 \mu \mathrm{g} / \mathrm{kg}$ of BW on $\mathrm{d}-14$ and -10 ; at $0.05 \mu \mathrm{g} / \mathrm{kg}$ of BW on $\mathrm{d}-7$ and -3 , and at $0.1 \mu \mathrm{g} / \mathrm{kg}$ of BW on $\mathrm{d} 3$ and 7 ; sterile saline solution was infused on the same day as LPS administration. 

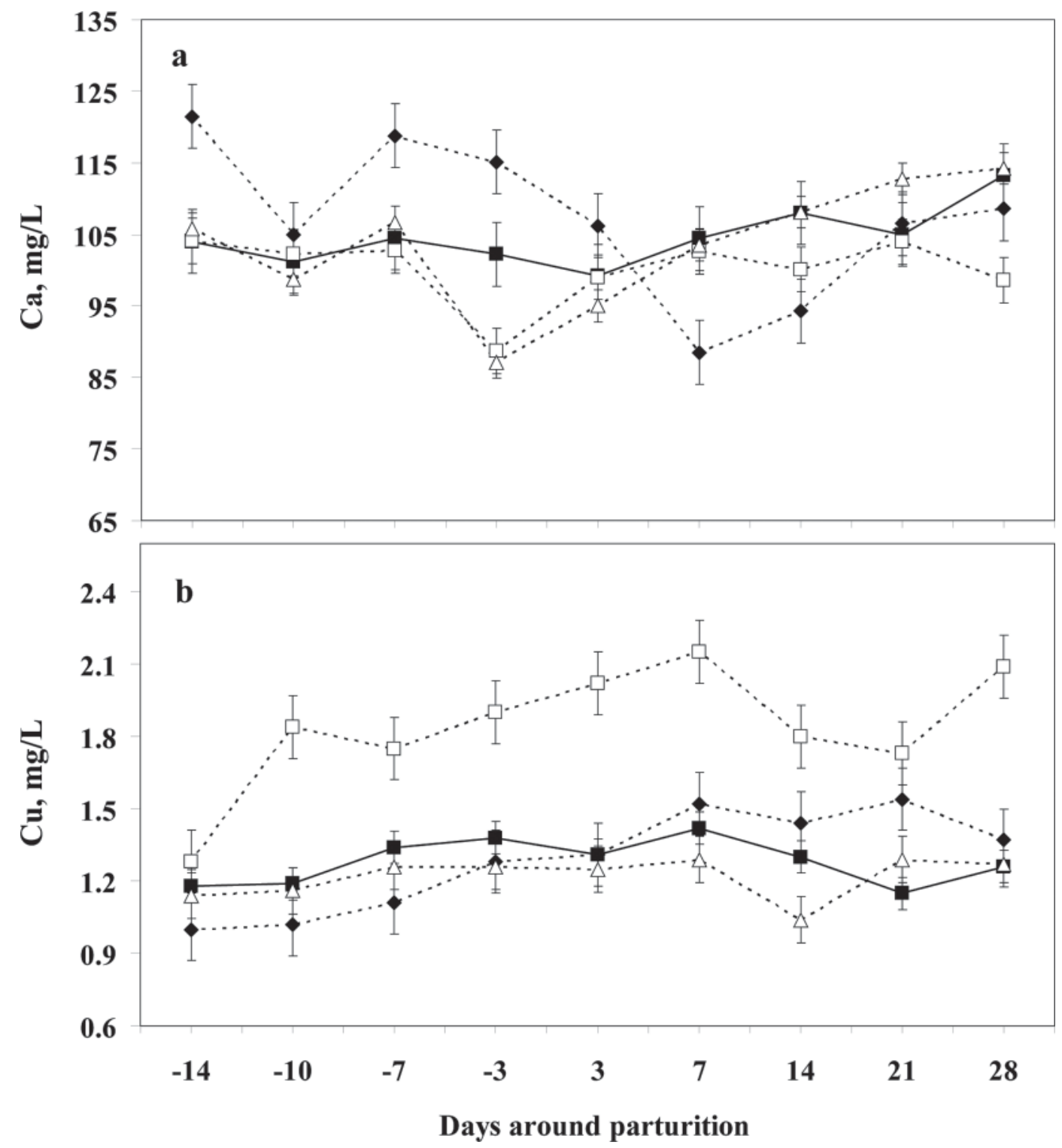

Figure 4. Data of calcium (a) and copper (b) in the plasma of periparturient dairy cows infused i.v. with saline ( $\square$ ) or LPS; the LPS-treated cows were classified as affected by left displaced abomasum $(\bullet)$ or retained placenta $(\triangle)$, or were clinically healthy $(\square)$. The LPS was i.v. infused at $0.01 \mu \mathrm{g} / \mathrm{kg}$ of BW on $\mathrm{d}-14$ and -10 ; at $0.05 \mu \mathrm{g} / \mathrm{kg}$ of BW on $\mathrm{d}-7$ and -3 , and at $0.1 \mu \mathrm{g} / \mathrm{kg}$ of BW on d 3 and 7 ; sterile saline solution was infused on the same day as LPS administration.

was associated with greater incidence of metabolic disturbances. More specifically, our data showed that the LPS-treated cows consumed less feed, particularly after parturition, and produced lower amounts of milk. Interestingly, the feed intake before parturition remained unchanged, which indicates no effect of prepartal endotoxemia on the feed intake potential of cows before parturition. In addition, this finding indicates that the amount of feed consumed prepartum alone was not related to, and cannot be predictive of, the development of LDA or RP and the resulting decreased feed intake postpartum. Our findings concerning the effects of endotoxemia on feed intake and milk production are in agreement with previously reported data by Waldron et al. (2003a), in which a single LPS administration was associated with minor effects on feed intake but strongly decreased milk production. It is known that LPS induces hypogalactia through systemic [e.g., the action of tumor necrosis factor (TNF)- $\alpha$ ] rather than local factors (Shuster et al., 1991). Moreover, research conducted by Theas et al. (1998) demonstrated that LPS inhibits prolactin secretion from rat pituitary gland. The latter finding suggests an indirect suppressive effect of LPS on milk production by inhibiting 

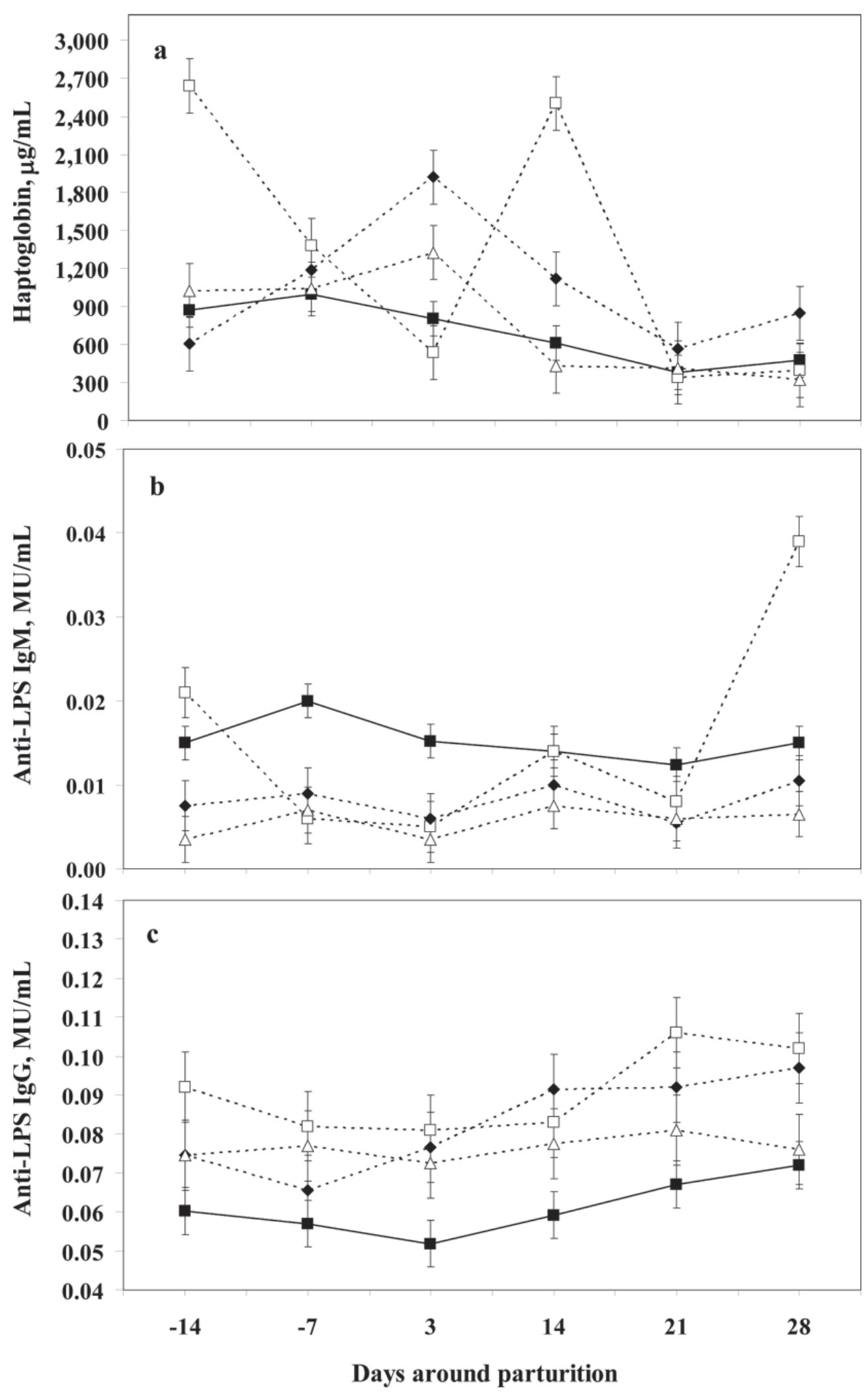

Figure 5. Data of haptoglobin (a), anti-LPS IgM (b), and anti-LPS IgG (c) in the plasma of periparturient dairy cows infused i.v. with saline $(\boldsymbol{\square})$ or LPS; the LPS-treated cows were classified as affected by left displaced abomasum $(\bullet)$ or retained placenta $(\Delta)$, or were clinically healthy ( $\square$ ). The LPS was i.v. infused at $0.01 \mu \mathrm{g} / \mathrm{kg}$ of BW on $\mathrm{d}-14$ and -10 ; at $0.05 \mu \mathrm{g} / \mathrm{kg}$ of BW on $\mathrm{d}-7$ and -3 , and at $0.1 \mu \mathrm{g} / \mathrm{kg}$ of $\mathrm{BW}$ on $\mathrm{d} 3$ and 7 ; sterile saline solution was infused on the same day as LPS administration. 
secretion of prolactin, which is involved in stimulation of milk synthesis. It is known that prolactin stimulates milk secretion in dairy cows (Lacasse et al., 2011).

Cluster analyses pinpointed 4 distinct clusters distinguished among each other, although the number of cows per each cluster was very low. Based on those data, a striking finding of this study was a greater incidence of LDA and RP in dairy cows infused with LPS. This finding directly implicates endotoxin in the etiopathology of LDA and RP. Our data showed that $50 \%$ of the cows (4 out of 8 cows) challenged with LPS before parturition retained their fetal membranes after parturition. Because RP increases the odds of developing metritis and infertility (Huzzey et al., 2009), this disorder is considered an economically important issue for the dairy industry (estimated cost: $\$ 285$ per case with an incidence of $7.8 \pm 0.2 \%$; Guard, 1999). To our knowledge, this is the first report demonstrating a direct involvement of prepartal intermittent endotoxemia in the etiopathogenesis of RP in dairy cows. The underlying mechanism(s) behind the association of prepartal LPS challenge and RP is not well understood at present. However, it is speculated that the increased occurrence of this disease in LPS-challenged cows might be due to an inhibiting effect of LPS on the tonicity of the uterine smooth muscle. Indeed, a single intravenous infusion of LPS was reported to cause hypomotility of smooth muscle tissue of reticulorumen (Eades, 1993). Another contributing factor in the greater incidence of RP in response to the intermittent endotoxemia might be the impaired cell-mediated immunity due to repeated i.v. infusions of LPS before parturition. In support of this assumption are data reported by Kimura et al. (2002), who observed a strong association between high incidence of RP and impaired neutrophil function before parturition. It is postulated that the intermittent exposure of cows to LPS before parturition in our study might have induced some degree of "LPS tolerance," and, therefore, a lowered responsiveness of neutrophils at parturition. Tolerance to LPS is a phenomenon in which the immune responses to LPS challenge are mitigated after repeated LPS administrations (Lehner and Hartung, 2002). Recently, it was shown that LPS tolerance induces a selective programming of neutrophil functions, whereby the tolerized neutrophils do not respond to LPS because of the downregulation of toll-like receptor-4 (Parker et al., 2005).

Left displaced abomasum is another common metabolic disease of dairy cattle, with unclear etiopathogenesis. It is characterized by varying degrees of abomasal distension and displacement to the left abdominal part (Fürll and Krüger, 1999; LeBlanc et al., 2005). The incidence of LDA ranges from 1.7 to $5.8 \%$ (Kelton et al., 1998), and its related costs are estimated to be
$\$ 312$ per case (Guard, 1999). Although the number of animals in the treated group was small $(\mathrm{n}=8)$ and only $2(25 \%)$ of those were affected by LDA, the clinical observations and the data obtained from plasma analyses (discussed separately below) support the hypothesis that LDA is mediated by an inflammatory state induced by intermittent endotoxemia around parturition. This assumption is supported by several other reports indicating that the atony of the abomasum observed during the disease may be related to presence of endotoxin in the plasma of sick cows (Fürll and Krüger, 1999; Poike and Fürll, 2000). The mechanism by which endotoxin contributes to development of the disease is related to direct inhibition of the abomasal smooth muscle motility and perturbation of Ca homeostasis (Delgado-Lecaroz et al., 2000). This is supported by observations reported by Vlaminck et al. (1985), who showed a dose-dependent decline and inhibition of abomasal motility following intravenous application of LPS or via a duodenal fistula, and by that of Kaze et al. (2004), who demonstrated a decrease in the strength of contractility of the abomasal muscle tissue from cows treated with endotoxin.

Although the LPS infusion model used in this study was intended to simulate a condition similar to that of peripartal endotoxemia, it should be kept in mind that the i.v. administered LPS might be removed from the circulation by multiple tissues including liver, spleen, lymph nodes, lungs, kidneys, adrenal glands, and muscles (Musson et al., 1978; Mathison and Ulevitch, 1979). Therefore, the responses of this study might differ somewhat from those when systemic endotoxin derives directly from the gastrointestinal tract or during infections of the uterus or mammary gland with gram-negative bacteria postpartum, whereby endotoxin may be cleared mostly by the liver (i.e., Kupffer cells) and lymph node macrophages (Andersen, 2003).

\section{Metabolite and Immune Responses to Intermittent Endotoxemia}

This study was undertaken primarily to evaluate the metabolic and immune responses of periparturient dairy cows to induced intermittent endotoxemia. An interesting finding of this research was the decreased concentration of plasma cholesterol in response to induced endotoxemia. The potential mechanism(s) by which endotoxin contributed to lowering the content of plasma cholesterol deserves further discussion. Blood cholesterol in ruminants derives mainly from endogenous synthesis in the epithelial cells of gastrointestinal tract, adipose tissue, and liver hepatocytes (Liepa et al., 1978; Viturro et al., 2009). Acetate and glucose are the major precursors to de novo synthesis of cholesterol in 
dairy cows (Liepa et al., 1978). Because plasma glucose was not different between the 2 treatment groups, and rumen acetate was supposed to be similar because cows were fed the same dietary compositions, we assumed that the synthesis of cholesterol should be the same; however, this was not the case. This suggested that other mechanisms, especially those related to clearance of cholesterol from circulation, might be involved in the changes of plasma cholesterol.

In previous research conducted by our team, we reported that lowered plasma cholesterol was associated with a systemic inflammatory state in periparturient dairy cows (Ametaj et al., 2005). Systemic LPS and associated inflammation triggers increased lipoproteinLPS clearance by increasing levels of low-density lipoprotein receptor (Viktorov and Yurkiv, 2005; Schvartz et al., 2008). In addition, lower cholesterol can be explained by the fact that cholesterol is the main precursor of bile acids (Parlesak et al., 2007), and increased bile secretion occurs during endotoxemia. Interestingly, Bertók (2004) demonstrated that bile acid-devoid rats develop endotoxemia. He showed that bile acids split the molecule of endotoxin into nontoxic fragments that are bound and neutralized by gastrointestinal proteins to prevent endotoxin translocation into the host's blood circulation (Bertók, 2004). Our finding with regard to hypocholesterolemia is indicative of the implication of intermittent endotoxemia and the resulting systemic inflammation on the metabolism of cholesterol-rich plasma lipoproteins (Chiarla et al., 2004).

Results of our study also demonstrated that the LPSLDA cows showed greater plasma BHBA on $d-10$ and 3 postpartum, whereas plasma BHBA in LPS-RP cows peaked at $14 \mathrm{~d}$ postpartum, in both cases reaching subketotic levels (Kelton et al., 1998). In periparturient dairy cows, plasma BHBA derives from oxidation of NEFA in hepatocytes during increased lipolysis due to lack of energy. In fact, feed intake in the LPS-infused cows decreased drastically after parturition, lowering the amount of energy and nutrient intake immediately after parturition. This might explain, at least in part, the fact that cows affected by LDA and RP had greater BHBA levels on d 3 and 14 postpartum, respectively. However, because plasma NEFA did not change in this study, we assumed that the effect of intermittent and gradual endotoxemia on increasing plasma BHBA could be attributed to the direct role of LPS on ketogenesis. Disturbed ketogenesis in the liver and greater BHBA levels have been reported following single administration of LPS in ruminant animals (Naylor and Kronfeld, 1986; Steiger et al., 1999; Waldron et al., 2003b). On the other hand, conflicting reports exist on the effects of endotoxemia on plasma NEFA in the published literature. For example, infusion of single doses of LPS decreased plasma NEFA in sheep (Naylor and Kronfeld, 1986) but increased those in heifers (Steiger et al., 1999), whereas the circulating NEFA were initially decreased and then increased in dairy cows (Waldron et al., 2003b).

Some discrepancies in the results obtained in the current study and those from previous studies that used single infusion of LPS can be attributed to the development of LPS tolerance due to repeated LPS exposure in the current study. For example, in our study, several plasma variables (e.g., glucose, NEFA, lactate, and insulin) and APP such as SAA and LBP did not respond to the LPS challenge. In contrast, single administration of LPS in cattle was associated with a biphasic response of plasma glucose: initial hyperglycemia followed by hypoglycemia several hours later (Lohuis et al., 1988; Werling et al., 1996; Steiger et al., 1999). In addition, administration of LPS resulted in hyperlactemia in sheep (Naylor and Kronfeld, 1986) and heifers (Steiger et al., 1999) and activation of APR (Carroll et al., 2009). The consensus is that downregulation of proinflammatory mediators responsible for APR, such as TNF- $\alpha$ and the reduced expression of toll like receptor-4, is the hallmark of LPS tolerance (Cavaillon et al., 2003). Although a large body of evidence exists regarding the mechanisms underlying LPS tolerance, its clinical relevance is not completely understood. It is not clear whether development of LPS tolerance triggered or facilitated development of metabolic perturbations in the current study; however, our data suggest that LPS tolerance may mask the presence of stronger metabolic and immune changes related to the occurrence of LDA and RP in dairy cows.

The fact that concentrations of APP such as SAA, LBP, and Hp in the plasma were greater around parturition in both groups of cows and decreased starting from d 10 postpartum indicates the presence of a mild APR in both groups of cows, probably elicited by exposure to rumen endotoxin caused by increasing the amount of grain in the diet postpartum in all cows. Our assumption is supported by data of studies in which rumen endotoxin increased dramatically when diets were switched from forage-rich to starch-rich, and this was associated with an activation of an APR in the short term (Emmanuel et al., 2008; Khafipour et al., 2009). This fact might also have modulated the expression of APR to exposure of LPS when cows were infused with larger doses of LPS challenge postpartum.

Interestingly, discriminant analysis of the data revealed that the greatest dissimilarity among the groups was between the responses of CON cows and those of the LPS-LDA group. The analysis also showed that plasma Ca, anti-LPS IgG, glucose, and cortisol were the best discrimination variables for cows treated with 
LPS and affected by LDA. Greater concentration of cortisol in the plasma of LPS-LDA cows indicated that exposure to LPS produced a stress-like condition. Research conducted in dairy cows and veal calves has demonstrated that i.v. infusion of LPS produces stress, as manifested by an increase in plasma cortisol (Hüsier and Blum, 2002; Waldron et al., 2003b). Production and release of cortisol limits the extent of the inflammatory response through its immunosuppressive activities, which includes decreasing the expression of genes for the proinflammatory molecules (Beishuizen and Thijs, 2003).

Intriguingly, the cows affected by LDA showed greater concentrations of $\mathrm{Ca}$ in plasma before parturition, but lower concentrations after parturition. This finding suggests that intermittent endotoxemia and the resulting changes in $\mathrm{Ca}$ metabolism may play a role in etiopathogenesis of LDA in dairy cows. A relationship between low levels of circulating $\mathrm{Ca}$ and reduced motility of rumen and abomasum smooth muscle and greater incidence of LDA were reported previously (Daniel, 1983; Delgado-Lecaroz et al., 2000). Research conducted by Van Winden et al. (2003) and LeBlanc et al. (2005) indicated that cows affected by LDA demonstrated disturbed plasma variables related to metabolism of carbohydrates, lipids, and minerals as well as impairment of liver function. However, this report is the first to pinpoint an interaction between intermittent endotoxemia and changing levels of circulating Ca associated with development of LDA before clinical presentation of this disease.

Cows in the LPS-LDA and LPS-RP groups had greater plasma Hp concentrations on d 3 postpartum. The presence of high concentrations of $\mathrm{Hp}$ before infusion of the largest dose of LPS (i.e., on d 3 postpartum) in LPS-LDA cows indicates the presence of an inflammatory state before the appearance of clinical signs. Our findings are in agreement with those of Stengärde et al. (2010), who reported greater concentrations of $\mathrm{Hp}$ in the plasma of cows affected by LDA. Haptoglobin has the ability to selectively antagonize LPS effects by suppressing monocyte production of TNF- $\alpha$, IL-10, and IL-12 and protecting the host from deleterious effects of LPS (Arredouani et al., 2005). In addition, $\mathrm{Hp}$ is released by liver hepatocytes during bacterial translocation. One of the known functions of $\mathrm{Hp}$ is to bind plasma free hemoglobin, released during hemolysis of red blood cells, and prevent utilization of iron contained in the hemoglobin by translocated bacteria (Wassell, 2000). Because $\mathrm{Hp}$ is considered an accurate marker of metritis (Huzzey et al., 2009), greater Hp concentrations in the plasma of cows affected by RP at $3 \mathrm{~d}$ postpartum may also be indicative of metritis, developed in a subclinical form in those cows.

The fact that cows treated repeatedly with LPS had greater concentrations of anti-LPS $\operatorname{IgG}$ and that this variable discriminated best for cows affected by LDA suggested that a secondary humoral immune response occurred in those cows, characterized by development of memory B cells (Barclay, 1995). In contrast, the lower plasma anti-LPS IgM antibodies in cows challenged with LPS indicated that exposure to LPS downregulated secretion of IgM antibodies or the primary humoral immune response. Immunoglobulin $\mathrm{M}$ is important not only as a primary response to LPS but also for mucosal immunity. This type of immunoglobulin, together with IgA, has been shown to play a significant role in mucosal immunity (Brandtzaeg, 1996). Other research has demonstrated that high plasma anti-LPS IgM is critical for clearance of circulating LPS (Márquez-Velasco et al., 2007). The lack of a significant effect of repeated LPS administration on IgA antibodies is related to the fact that $\operatorname{IgA}$ antibodies are released more into the mucosal layers instead of the blood circulation. In agreement with this postulate are data reported by Orlans et al. (1978), showing that IgA antibodies disappear quickly from blood to the bile. It is known that anti-LPS IgA antibody-producing B cells are located mainly in the gastrointestinal tract (Orlans et al., 1978).

Although cows in the LPS-NO group did not show clinical signs of disease, those cows had greater plasma $\mathrm{Hp}$ on $\mathrm{d}-14$ and 14 , greater circulating $\mathrm{Cu}$, and the lowest concentration of cholesterol in plasma around parturition. Additionally, those cows had lower feed intake and milk production, indicating that intermittent endotoxemia is associated with development of an inflammatory state without clear clinical signs of disease. Greater $\mathrm{Cu}$ concentration in the plasma indicated development of inflammatory processes, which are known to cause significant perturbations of $\mathrm{Cu}$ metabolism in both humans and cows (Conforti et al., 1982; Conner et al., 1989; Zebeli et al., 2010). Lack of clinical signs in some of the LPS-challenged cows also suggested that cow-to-cow variability played a role in the response to repeated intravenous LPS. Jacobsen et al. (2005) demonstrated interindividual variation of dairy cows in response to intravenous challenge with LPS.

It is important to point out that different responses obtained from individual cows to the LPS challenge are related to the individual genetic make-up of the cows. These responses are in agreement with what we and others have reported previously - that the cow factor is very important in how cows respond to LPS challenge (Jacobsen et al., 2004, 2005; Elsasser et al., 2005; Zebeli and Ametaj, 2009). Thus, it is important to consider 
individual responses when challenging dairy cows with LPS or other bacterial products.

\section{CONCLUSIONS}

Intermittently induced endotoxemia elicited major changes in feed intake and milk production in dairy cows and was associated with a greater incidence of metabolic disorders such as LDA and RP. Additionally, infusion of LPS triggered alterations in several plasma variables, including cholesterol, $\mathrm{BHBA}, \mathrm{Hp}, \mathrm{Ca}, \mathrm{Cu}$, anti-LPS IgG, and anti-LPS IgM. Although some cows in the LPS-treated group did not show clinical signs of disease, those cows demonstrated a systemic inflammatory state coupled with metabolic changes in the plasma. In conclusion, results suggest a potential role of chronic endotoxemia in the development of metabolic disturbances in dairy cows and in increasing the incidence of metabolic diseases during the periparturient period. Further research is warranted to elucidate longterm effects of endotoxemia on health and productivity of dairy cows as well as on the development of novel prophylactic strategies for prevention of endotoxemia in transition dairy cows.

\section{ACKNOWLEDGMENTS}

We acknowledge the financial support of Alberta Milk (Edmonton, Alberta, Canada), Alberta Livestock Industry Development Fund (Edmonton, Alberta, Canada), and Natural Sciences and Engineering Research Council of Canada (Ottawa, Ontario, Canada). The assistance of D. G. V. Emmanuel and R. Psutka (University of Alberta, Edmonton, AB, Canada) with the sampling and laboratory analyses is highly appreciated. We are grateful to the technical staff at Dairy Technology and Research Centre, University of Alberta, for their help with and care of the cows.

\section{REFERENCES}

Ametaj, B. N., B. J. Bradford, G. Bobe, R. A. Nafikov, Y. Lu, J. W Young, and D. C. Beitz. 2005. Strong relationships between mediators of the acute phase response and fatty liver in dairy cows. Can. J. Anim. Sci. 85:165-175.

Ametaj, B. N., D. G. V. Emmanuel, Q. Zebeli, and S. M. Dunn. 2009b. Feeding high proportions of barley grain in a total mixed ration perturbs diurnal patterns of plasma metabolites in lactating dairy cows. J. Dairy Sci. 92:1084-1091.

Ametaj, B. N., K. M. Koenig, S. M. Dunn, W. Z. Yang, Q. Zebeli, and K. A. Beauchemin. 2009a. Backgrounding and finishing diets are associated with inflammatory responses in feedlot steers. J. Anim. Sci. 87:1314-1320.

Ametaj, B. N., Q. Zebeli, and S. Iqbal. 2010. Nutrition, microbiota, and endotoxin-related diseases in dairy cows. R. Bras. Zootec. 39(Suppl. 1):433-444.

Andersen, P. H. 2003. Bovine endotoxicosis: Some aspects of relevance to production diseases. Acta Vet. Scand. Suppl. 98:141-155.
Arredouani, M. S., A. Kasran, J. A. Vanoirbeek, F. G. Berger, H Baumann, and J. L. Ceuppens. 2005. Haptoglobin dampens endotoxin-induced inflammatory effects both in vitro and in vivo. Immunology 114:263-271.

Barclay, G. R. 1995. Endogenous endotoxin-core antibody (EndoCAb) as a marker of endotoxin exposure and a prognostic indicator: A review. Prog. Clin. Biol. Res. 392:263-272.

Beishuizen, A., and L. G. Thijs. 2003. Endotoxin and the hypothalamopituitary-adrenal (HPA) axis. J. Endotoxin Res. 9:3-24.

Bertók, L. 2004. Bile acids in physico-chemical defense. Pathophysiology 11:139-145.

Bertoni, G., E. Trevisi, X. Han, and M. Bionaz. 2008. Effects of inflammatory conditions on liver activity in puerperium period and consequences for performance in dairy cows. J. Dairy Sci. 91:3300-3310.

Bionaz, M., E. Trevisi, L. Calamari, F. Librandi, A. Ferrari, and G. Bertoni. 2007. Plasma paraoxonase, health, inflammatory conditions, and liver function in transition dairy cows. J. Dairy Sci. 90:1740-1750.

Brandtzaeg, P. 1996. History of oral tolerance and mucosal immunity. Ann. N. Y. Acad. Sci. 778:1-27.

Canadian Council on Animal Care. 1993. Guide to the Care and Use of Experimental Animals. Vol. 1. 2nd ed. CCAC, Ottawa, Ontario, Canada.

Carroll, J. A., R. R. Reuter, C. C. Chase Jr., S. W. Coleman, D. G Riley, D. E. Spiers, J. D. Arthington, and M. L. Galyean. 2009 Profile of the bovine acute-phase response following an intravenous bolus-dose lipopolysaccharide challenge. Innate Immun. 15:81-89.

Cavaillon, J. M., C. Adrie, C. Fitting, and M. Adib-Conquy. 2003 Endotoxin tolerance: Is there a clinical relevance? J. Endotoxin Res. 9:101-107.

Chiarla, C., I. Giovannini, and J. H. Siegel. 2004. The relationship between plasma cholesterol, amino acids and acute phase proteins in sepsis. Amino Acids 27:97-100.

Conforti, A., L. Franco, R. Milanino, and G. P. Velo. 1982. Copper and ceruloplasmin $(\mathrm{Cp})$ concentrations during the acute inflammatory process in the rat. Agents Actions 12:303-307.

Conner, J. G., P. D. Eckersall, A. Wiseman, R. K. Bain, and T. A. Douglas. 1989. Acute phase response in calves following infection with Pasteurella haemolytica, Ostertagia ostertagi and endotoxin administration. Res. Vet. Sci. 47:203-207.

Daniel, R. C. W. 1983. Motility of the rumen and abomasum during hypocalcaemia. Can. J. Comp. Med. 47:276-280.

Delgado-Lecaroz, R., L. D. Warnick, C. L. Guard, M. C. Smith, and D. A. Barry. 2000. Cross-sectional study of the association of abomasal displacement or volvulus with serum electrolyte and mineral concentrations in dairy cows. Can. Vet. J. 41:301-305.

Eades, S. C. 1993. Endotoxemia in dairy cattle: Role of eicosanoids in reticulorumen stasis. J. Dairy Sci. 76:414-420.

Elsasser, T. H., J. W. Blum, and S. Kahl. 2005. Characterization of calves exhibiting a novel inheritable TNF-alpha hyperresponsiveness to endotoxin: Association with increased pathophysiological complications. J. Appl. Physiol. 98:2045-2055.

Emmanuel, D. G., S. M. Dunn, and B. N. Ametaj. 2008. Feeding high proportions of barley grain stimulates an inflammatory response in dairy cows. J. Dairy Sci. 91:606-614.

Fürll, M., and M. Krüger. 1999. Alternative Möglichkeiten zur Prophylaxe der Dislocatio abomasi (DA) beim Rind. Prakt. Tierarzt 80:81-90.

Goff, J. P. 2006. Major advances in our understanding of nutritional influences on bovine health. J. Dairy Sci. 89:1292-1301.

Guard, C. 1999. Set up fresh and milking cows for successful A. I. Hoard's Dairyman 8-9.

Hüsier, B. R., and J. W. Blum. 2002. Metabolic and endocrine changes in response to endotoxin administration with or without oral arginine supplementation. J. Dairy Sci. 85:1927-1935.

Huzzey, J. M., T. F. Duffield, S. J. LeBlanc, D. M. Veira, D. M. Weary, and M. A. G. von Keyserlingk. 2009. Short communication: Haptoglobin as an early indicator of metritis. J. Dairy Sci. 92:621-625.

Jacobsen, S., P. H. Andersen, T. Toelboell, and P. M. Heegaard. 2004 Dose dependency and individual variability of the lipopolysaccha- 
ride-induced bovine acute phase protein response. J. Dairy Sci. 87:3330-3339.

Jacobsen, S., T. Toelboell, and P. H. Andersen. 2005. Dose dependency and individual variability in selected clinical, haematological and blood biochemical responses after systemic lipopolysaccharide challenge in cattle. Vet. Res. 36:167-178.

Kaze, C., M. Mevissen, G. Hirsbrunner, and A. Steiner. 2004. Effect of endotoxins on contractility of smooth muscle preparatios from the bovine abomasal antrum. Dtsch. Tierarztl. Wochenschr. 111:28-35.

Kelton, D. F., K. D. Lissemore, and R. E. Martin. 1998. Recommendations for recording and calculating the incidence of selected clinical diseases of dairy cattle. J. Dairy Sci. 81:2502-2509.

Khafipour, E., D. O. Krause, and J. C. Plaizier. 2009. A grain-based subacute ruminal acidosis challenge causes translocation of lipopolysaccharide and triggers inflammation. J. Dairy Sci. 92:10601070.

Kimura, K., J. P. Goff, M. E. Kehrli Jr., and T. A. Reinhardt. 2002. Decreased neutrophil function as a cause of retained placenta in dairy cattle. J. Dairy Sci. 85:544-550.

Lacasse, P., V. Lollivier, R. M. Bruckmaier, Y. R. Boisclair, G. F. Wagner, and M. Boutinaud. 2011. Effect of the prolactin-release inhibitor quinagolide on lactating dairy cows. J. Dairy Sci. 94:1302-1309.

LeBlanc, S. J., K. E. Leslie, and T. F. Duffield. 2005. Metabolic predictors of displaced abomasum in dairy cattle. J. Dairy Sci. 88:159-170.

Lehner, M. D., and T. Hartung. 2002. Endotoxin tolerance mechanisms and beneficial effects in bacterial infection. Rev. Physiol. Biochem. Pharmacol. 144:95-141.

Liepa, G. U., D. C. Beitz, and J. R. Linder. 1978. Cholesterol synthesis in ruminating and nonruminating goats. J. Nutr. 108:535-543.

Lohuis, J. A., J. H. Verheijden, C. Burvenich, and A. S. van Miert. 1988. Pathophysiological effects of endotoxins in ruminants. Vet. Q. 10:117-125.

Loor, J. J., H. M. Dann, N. A. J. Guretzky, R. E. Everts, R. Oliveira, C. A. Green, N. B. Litherland, S. L. Rodriguez-Zas, and H. A. Lewin. 2006. Plane of nutrition prepartum alters hepatic gene expression and function in dairy cows as assessed by longitudinal transcript and metabolic profiling. Physiol. Genomics 27:29-41.

López-Soriano, F. J., and D. H. Williamson. 1994. Acute effects of endotoxin (lipopolysaccharide) on tissue lipid metabolism in the lactating rat. The role of delivery of intestinal glucose. Mol. Cell. Biochem. 141:113-120.

Márquez-Velasco, R., F. Massó, R. Hernández-Pando, L. F. Montaño, R. Springall, L. M. Amezcua-Guerra, and R. Bojalil. 2007. LPS pretreatment by the oral route protects against sepsis induced by cecal ligation and puncture. Regulation of proinflammatory response and IgM anti-LPS antibody production as associated mechanisms. Inflamm. Res. 56:385-390.

Mathison, J. C., and R. J. Ulevitch. 1979. The clearance, tissue distribution, and cellular localization of intravenously injected lipopolysaccharide in rabbits. J. Immunol. 123:2133-2143.

Musson, R. A.. D. C. Morrison, and R. J. Ulevitch. 1978. Distribution of endotoxin (lipopolysaccharide) in the tissues of lipopolysaccharide-responsive and -unresponsive mice. Infect. Immun. 21:448-457.

Nagaraja, T. G., E. E. Bartley, L. R. Fina, H. D. Anthony, and R. M. Bechtle. 1978. Evidence of endotoxins in the rumen bacteria of cattle fed hay or grain. J. Anim. Sci. 47:226-234.

NRC. 2001. Nutrient Requirements of Dairy Cattle. 7th rev. ed. Natl. Acad. Sci., Washington, DC.

Naylor, J. M., and D. S. Kronfeld. 1986. Relationships between metabolic changes and clinical signs in pregnant sheep given endotoxin. Can. J. Vet. Res. 50:402-409.

Orlans, E., J. Peppard, J. Reynolds, and J. Hall. 1978. Rapid active transport of immunoglobulin A from blood to bile. J. Exp. Med. 147:588-592.

Parker, L. C., E. C. Jones, L. R. Prince, S. K. Dower, M. K. B. Whyte, and I. Sabroe. 2005. Endotoxin tolerance induces selective alterations in neutrophil function. J. Leukoc. Biol. 78:1301-1305.
Parlesak, A., S. Schaeckeler, L. Moser, and C. Bode. 2007. Conjugated primary bile salts reduce permeability of endotoxin through intestinal epithelial cells and synergize with phosphatidylcholine in suppression of inflammatory cytokine production. Crit. Care Med. $35: 2367-2374$

Poike, A., and M. Fürll. 2000. Zur Epidemiologie der Labmagenverlagerung (Dislocatio abomasi) in Mitteldeutschland. Pages 29-39 in Proc. Int. Workshop über Ätiologie, Pathogenese, Diagnostik, Prognose, Therapie und Prophylaxe der Dislocatio abomasi. M. Fürll, ed. Universitätsverlag Leipzig, Leipzig, Germany.

Schvartz, Y. Sh., L. M. Polyakov, M. I. Dushkin, and E. N. Pivovarova. 2008. Modification and clearance of low-density lipoproteins during the formation of endotoxin-lipoprotein complexes. Bull. Exp. Biol. Med. 145:430-432.

Shuster, D. E., R. J. Harmon, J. A. Jackson, and R. W. Hemken. 1991. Reduced lactational performance following intravenous endotoxin administration to dairy cows. J. Dairy Sci. 74:3407-3411.

Steiger, M., M. Senn, G. Altreuther, D. Werling, F. Sutter, M. Kreuzer, and W. Langhans. 1999. Effect of a prolonged low-dose lipopolysaccharide infusion on feed intake and metabolism in heifers. J. Anim. Sci. 77:2523-2532.

Stengärde, L., K. Holtenius, M. Tråvén, J. Hultgren, R. Niskanen, and U. Emanuelson. 2010. Blood profiles in dairy cows with displaced abomasums. J. Dairy Sci. 93:4691-4699.

Theas, M. S., A. De Laurentis, M. Lasaga, D. Pisera, B. H. Duvilanski, and A. Seilcovich. 1998. Effect of lipopolysaccharide on tumor necrosis factor and prolactin release from rat anterior pituitary cells. Endocrine 8:241-245.

Van Winden, S. C., R. Jorritsma, K. E. Müller, and J. P. Noordhuizen. 2003. Feed intake, milk yield, and metabolic parameters prior to left displaced abomasum in dairy cows. J. Dairy Sci. $86: 1465-1471$.

Viktorov, A. V., and V. A. Yurkiv. 2005. Binding of LPS and LPS-LDL complexes to rat hepatocytes. Bull. Exp. Biol. Med. 139:441-443.

Viturro, E., M. Koenning, A. Kroemer, G. Schlamberger, S. Wiedemann, M. Kaske, and H. H. D. Meyer. 2009. Cholesterol synthesis in the lactating cow: Induced expression of candidate genes. J. Steroid Biochem. Mol. Biol. 115:62-67.

Vlaminck, K., H. Van Meirhaeghe, C. Van den Hende, W. Oyaert, and E. Muylle. 1985. Einfluß von Endotoxinen auf die Labmagenentleerung beim Rind. Dtsch. Tierarztl. Wochenschr. 92:392395

Waldron, M. R., T. Nishida, B. J. Nonnecke, and T. R. Overton. 2003b. Effect of lipopolysaccharide on indices of peripheral and hepatic metabolism in lactating cows. J. Dairy Sci. 86:3447-3459.

Waldron, M. R., B. J. Nonnecke, T. Nishida, R. L. Horst, and T. R. Overton. 2003a. Effect of lipopolysaccharide infusion on serum macromineral and vitamin $\mathrm{D}$ concentrations in dairy cows. J. Dairy Sci. 86:3440-3446.

Wassell, J. 2000. Haptoglobin: Function and polymorphism. Clin. Lab. 46:547-552.

Werling, D., F. Sutter, M. Arnold, G. Kun, P. C. J. Tooten, E. Gruys, M. Kreuzer, and W. Langhans. 1996. Characterisation of the acute phase response of heifers to a prolonged low dose infusion of lipopolysaccharide. Res. Vet. Sci. 61:252-257.Zalkovic, P., M. A. MacLean, and D. J. Ambrose. 2001. A simple procedure to secure an indwelling jugular vein catheter to the neck of cattle for repeated blood sampling. Can. Vet. J. 42:940-942.

Zebeli, Q., and B. N. Ametaj. 2009. Relationships between rumen lipopolysaccharide and mediators of inflammatory response with milk fat production and efficiency in dairy cows. J. Dairy Sci. 92:3800-3809.

Zebeli, Q., S. M. Dunn, and B. N. Ametaj. 2010. Strong associations among rumen endotoxin and acute phase proteins with plasma minerals in lactating cows fed graded amounts of concentrate. J. Anim. Sci. 88:1545-1553. 